Published in final edited form as:

Cytotherapy. 2007 ; 9(2): 111-122.

\title{
Immune Reconstitution in Children After Unrelated Cord Blood Transplantation
}

\author{
Paul Szabolcs, MD ${ }^{\star}, \S$ and Donna Niedzwiecki, Ph.D.\$ \\ * Department of Pediatrics, Pediatric Blood and Marrow Transplant Program, Duke University, Durham, \\ NC 27710 \\ § Department of Immunology, Duke University, Durham, NC 27710
}

- Department of Biostatistics and Bioinformatics, Duke University Medical Center, Durham, NC 27710

\section{Introduction}

Cord blood as a hematopoietic graft was first used in 1989 for a child with severe Fanconi anemia [1]. Since 1993, when the first ever unrelated cord blood transplant (UCBT) was performed at Duke University [2], >9000 such transplants are estimated to have been performed worldwide [3]. The increasing use of cord blood in the unrelated donor setting is partially explained by the following significant findings. UCBT apparently offers a similar [4] or reduced risk [5] of severe graft-versus-host-disease (GVHD) permitting a less stringent criteria for HLA matching, reviewed in [3].

UCBT is a life-saving form of HCT, however, it is limited by the high incidence of opportunistic infections, most of which are viral. OI is the major cause of transplant related mortality during the first 6 months after UCBT and is caused by delays in immune reconstitution. Immune reconstitution is a highly complex process influenced by both graft (e.g. cell dose, histocompatibility, donor serology) and recipient related factors (age, previous therapy, conditioning regimen, past infectious exposures, etc). Adaptive immunity is the cumulative effect of a network of phenotypically distinct and highly specialized leukocyte subpopulations. Antigen presenting dendritic cell (DC), effector, memory, and regulatory lymphocyte subsets are the principal players of this network. Instructional signals from the innate immune system shape the quality and net effect of antigen-specific immunity.

While attaining normal ranges of specific leukocyte subsets have been used extensively, protection from clinical infections is the best surrogate marker of successful immune reconstitution.

\section{The high incidence of infections after UCBT occurs predominantly within the first 3-4 months after transplant}

Infection-related mortality (IRM) is the primary or secondary cause of death (with or without another major cause such as GvHD) in $\geq 50 \%$ of deaths after UCBT with the majority of them occurring in the first 100 days [3,6-8]. The impact of early infections is highlighted by a report

\footnotetext{
Address Correspondence to: Paul Szabolcs, M.D., Pediatric Blood and Marrow Transplant Program, Box 3350, Duke University Medical Center, Durham, NC 27705, USA, Tel: 1-919-668-1122, FAX: 1-919-668-1180, E-mail: szabo001@ mc.duke.edu.

Publisher's Disclaimer: This is a PDF file of an unedited manuscript that has been accepted for publication. As a service to our customers we are providing this early version of the manuscript. The manuscript will undergo copyediting, typesetting, and review of the resulting proof before it is published in its final citable form. Please note that during the production process errors may be discovered which could affect the content, and all legal disclaimers that apply to the journal pertain.
} 
from the International Bone Marrow Transplant Registry (IBMTR). Outcome after transplantation was analyzed between recipients of either cord blood $(n=150)$ or from marrow that was from HLA-matched $(n=367)$ or mismatched for one HLA antigen $(n=83)$ [9]. Infection related mortality (IRM) within 100 days after transplantation was significantly higher among recipients of mismatched cord blood than among recipients of either HLA-matched marrow or mismatched marrow $(45 \%, 21 \%$, and $24 \%$, respectively; $\mathrm{P}=0.01)$. However, beyond day 100 , the proportions of infection-related deaths were similar in the three groups. A multicenter study from Spain also found increased occurrence of severe infections during the first 100 days after UCBT $(73 \%)$ than in the BMT/PBSC groups $(50 \% ; \mathrm{p}=0.02)$ [10]. Barker et al from Minnesota also documented higher cumulative incidence of serious infections among children receiving UCBT $(58 \%)$ immediately post-transplant in contrast with recipients of unmanipulated BM (35\%, p=0.04) [11]. However, subsequently there was a trend towards less serious infection in the UCBT group similar to the findings of IBMTR report [9], suggesting that the immune deficit that seems to be so heightened in the immediate post-UCBT period is followed by significant improvements of immunity. Although causal relationship can not be established directly, this period coincides with the time of thymic recovery. When the Minnesota group analyzed two BMT cohorts separately, patients in the T cell depleted group demonstrated significantly more viral $(\mathrm{p}<0.01)$, but not bacterial, infections than either UCBT or unmodified bone marrow recipients beyond 6 months. These findings together with the report by the COBLT investigators [12] suggest an important protective role for post-thymic $\mathrm{T}$ cells infused in the graft regardless whether they include antigen experienced (marrow) or almost exclusively antigen naïve (cord blood) T cells.

\section{General principles of immune recovery after HCT}

Immunoablation is an obligatory consequence of most myeloablative preparative regimens. While as a whole the innate immune system appears to recover rapidly, within weeks after $\mathrm{HCT}$, the recovery of functional B and T lymphocytes (adaptive immunity) is far more difficult to achieve [13-15]. Following the resolution of pancytopenia after HCT, the first wave of T cells emerging in the lymphopenic host are peripherally expanding $\mathrm{T}$ lymphocytes representing the thymic-independent pathway [16]. However, the antigen-driven expansion of peripheral $\mathrm{T}$ cells leads to a limited and skewed T cell receptor (TCR) repertoire [16]. Several weeks/months later a second wave of $\mathrm{T}$ cells emerge developing from donor-derived common lymphocyte progenitors (CLP) as the result of de novo thymopoiesis. In the absence of significant GvHD this thymic-dependent pathway $[14,15]$ is solely responsible for a fully diverse T cell repertoire. Interestingly, by 2 years after HCT higher TCR diversity may be attained in CB recipients than in recipients of BMT [17] indicating the existence of an efficient thymic-dependent pathway.

\section{Unique features of neonatal lymphocytes and dendritic cells in cord blood}

CB contains significantly higher absolute numbers of T, NK, and B lymphocytes than adult peripheral blood (PB) or even marrow [18-21]. However, most UCB T cells infused with the graft are CD45RA ${ }^{+} / \mathrm{CD} 2 \mathrm{~L}^{+}$'Recent Thymic Emigrants' (RTE) with smaller TCR $\gamma \delta$ and $\mathrm{CD}^{2} 5^{+}$subsets [20]. CB T cells have been even called immature compared to bulk adult T cells due to their impaired capacity for cytokine production [22] and diminished lytic activity [23]. While RTE predominate in cord blood it contains some antigen-experienced T cells, most notably those specific for maternal minor histocompatibility antigens [24]. The reduced capacity of bulk cord blood mononuclear cells to secrete cytokines and lymphokines has been demonstrated to affect GM-CSF, M-CSF, IL-4, IL-8, IL-12, IL-15, and IL-18, reviewed in $[25,26]$. There is reduced expression of NFATc2 (nuclear factor of activated T cells c2), a critical transcription factor necessary for up-regulation of these and other cytokines known to amplify T-cell responses [27]. The relative cytolytic deficiency of CB T cells is associated with absent expression of Granzymes and Perforin [28], essential for eradicating viral pathogens. 
$\mathrm{CD} 25^{+} \mathrm{T}$ cells in cord blood are naturally occurring regulatory $\mathrm{T}$ cells [29] with potent suppressor function as opposed to peripherally activated CD25+ cells [30]. Fewer UCB T cells display HLA-DR and CCR-5 activation markers, while the $\mathrm{CD} 8^{+} / \mathrm{CD} 57^{+} / \mathrm{CD} 28^{-}$and $\mathrm{CD} 8^{+} /$ CD45RA ${ }^{+} / \mathrm{CD} 27^{-}$'cytotoxic', along with the 'skin homing' CLA+ T cell subsets are absent altogether [20]. Compared with adult blood more cord blood $\mathrm{T}$ cells progress through cell cycle and enter apoptosis. However, unlike in adult PB the majority of proliferating Ki-67+ T cells in $\mathrm{UCB}$ retain a CD45RA ${ }^{+} / \mathrm{RO}^{-}, \mathrm{CD}^{-} 9^{-}, \mathrm{CD} 25^{-}, \mathrm{HLA}-\mathrm{DR}^{-}$'resting' phenotype [20,31]. Unlike in adult blood there is also significant expression of telomerase in CB T cells [31]. In contrast with T cells, CB NK cells are functionally "mature" with comparable or better lytic activity than their bone marrow derived counterparts [32]. Not surprisingly, 'naïve' B lymphocytes are in excess in CB with an abundance of "B1+" $\mathrm{CD} 5^{+} \mathrm{B}$ cells and CD23immature B cells $[20,33]$.

\section{Placental factors shape the functional profile of fetal T cells and dendritic cells}

Despite an overlapping CD45RA ${ }^{+} / \mathrm{CD} 28^{+} / \mathrm{CD} 27^{+}$phenotype $\mathrm{CB} \mathrm{T}$ cells are fundamentally different from 'naïve' adult $\mathrm{T}$ cells mostly because they demonstrate a relative Th2/Tc2 bias. Multiple tiers of Th2/Tc2 biasing factors exist at the maternal-fetal interface; IL-10 secreted by cytotrophoblasts [34], reduced local Tryptophan levels [35], increased progesterone levels [36] and other placental factors ( $\mathrm{IL}^{-4}, \mathrm{PGE}_{2}$ ), reviewed in [37 ]. This immunoregulatory network could be viewed as part of an evolutionary adaptation to permit survival and avoid rejection of the fetus. Fas-ligand expression at the maternal-fetal interface may eliminate $\mathrm{T}$ cells activated despite these factors above [38]. The exuberant production of IL-13 primarily by $\mathrm{CD}^{+} \mathrm{T}$ cells [39] is in sharp contrst with lower IFN $\gamma$ production that persists even after stimulation via CD3/CD28 signaling and exogenous IL-2 [39]. This is a consequence of differential patterns of methylation of the IFN $\gamma$ promoter [40]. Independently, impaired APC function of neonatal/cord blood dendritic cells (DC) restricts the potential for optimal Th1 cell responses in neonates due to their low IL-12 expression [41-43]. Despite these limits there is evidence that intrauterine viral infections e.g. CMV could generate partial Th1 immune responses [37], though persistent and selective deficiency of antiviral Th1 $\mathrm{CD}^{+} \mathrm{T}$ cell is documented into early childhood [44].

\section{Previously reported features of immune recovery after UCBT}

Although mitogenic proliferative responses may already reach normal range in children 6-9 months after UCBT, T cell reconstitution is gradual and typically does not reach age appropriate numbers before 9 months. Meanwhile, T cell recovery in adults typically extends beyond the first year, presumably related to the inferior output of $\mathrm{TREC}^{+}$naïve $\mathrm{T}$ cells in older recipients [45]. Notably, NK cell recovery is prompt both in numbers and function in both adults and children by the first 2 months similar to recipients of bone marrow [46,47]. Significant B lymphocyte recovery starts $\sim 3-4$ months after transplant that may reach normal numbers by 6-9 months [48].

While the incidence of life threatening viral infections is high in the first 6 months after UCBT suggesting deficits in $\mathrm{T}$ cell numbers or function, when monitored beyond 9 months posttransplant the speed of $\mathrm{T}$ cell recovery seems to be at least comparable [49] to or even better than that seen after unrelated BMT, [21,46,50]. Investigators from the Cord Blood Transplantation Study (COBLT) analyzed antigen-specific proliferation after UCBT [12]. Children with malignancies were longitudinally tested over the first 3 years post transplant for herpes virus specific responses (HSV,VZV,CMV). Approximately $43 \%$ of the patients studied eventually developed a positive T-lymphocyte proliferative response to at least one herpes virus at some point over the 3 year observational period. In a few, proliferative responses 
developed as early as within the first 30-50 days, indicating that naive T lymphocytes transferred in the graft can give rise to antigen-specific T-lymphocyte immunity before thymic recovery[12]. Significantly, patients with a proliferative response at any time in the first 3 years to any of the herpesviruses had a lower probability of leukemia relapse and a higher overall survival [12]. One may speculate that the superior proliferative $\mathrm{T}$ cell response represents a powerful surrogate marker for functional immune reconstitution lading to more effective graftversus-leukemia (GVL) activity. However, the development and kinetics of protective antigenspecific function was not evaluable [51].

\section{Patient and graft specific factors predict the risk of death from opportunistic infections (OI) in the first 6 months after UCBT}

Over the past 5 years we have studied the reconstitution of immunity in the immediate postUCBT period (prior to thymic recovery) in $>150$ pediatric recipients of single unit UCB at Duke University to identify surrogate immune markers for those at risk for OI.

Several graft and patient-specific variables were also identified as significant factors when the laboratory measurements of DC and T cell reconstitution were analyzed. To determine the impact of patient and graft-specific factors on 6-month post-UCBT OI-related mortality we reviewed all consecutive pediatric UCB recipients transplanted at Duke University Medical Center between June 1999 and Oct. 2005 to overlap with the immune monitoring studies [52]. Three hundred thirty (330) pediatric recipients of single UCB grafts were identified. Those receiving a second transplant for primary graft failure were excluded. Two hundred twenty (220) of the 330 patients (67\%) were alive at 6 months, Figure 1 . Of those who died by 6 months, (58\%) were identified with OI (viral, fungal, protozoal infections) implicated as a cause of death (Fig 1). Those who died prior to 6 months and for whom OI was not implicated as a cause of death were omitted from the study dataset, resulting in 284 patients. Of these 284 patients, 220 patients $(77 \%)$ were alive at 6 months and $64(23 \%)$ died at or before 6 months with cause of death related to OI. Twenty two (22) patients died related to adenovirus infection and twelve (12) due to CMV infection, rendering these two viruses the cause in $>50 \%$ of all OI related deaths.

A logistic regression model was used to investigate the impact of ten demographic and clinical characteristics (gender, race, age at UCBT, CMV serology, HLA mismatches, malignancy, total body irradiation, total graft cell dose $/ \mathrm{kg}, \mathrm{CD}^{+}$graft cell dose $/ \mathrm{kg}$ and $\mathrm{CD} 3^{+}$graft cell dose/ $\mathrm{kg}$ ) on the risk of death due to OI by 6 months post UCBT. A 3-level categorical variable was also created from the two variables "malignancy" and "total body irradiation" describing the indication for UCBT (non-malignant condition treated with chemotherapy alone; malignancy treated with regimens including total body irradiation (TBI); malignancy treated without TBI).

In univariate analyses, gender $(\mathrm{p}=0.28)$, race $(0.12)$ and TBI $(\mathrm{p}=0.80)$ did not predict 6 -month death due to OI. Malignancy $(\mathrm{p}=0.07)$ was marginally associated with a greater probability of 6-month death due to OI. Malignancy without TBI was also associated with a marginally higher probability of 6-month death due to $\mathrm{OI}(\mathrm{p}=0.04)$. A significantly greater probability of 6-month OI-related death was associated with $C M V$ positive serology $(\mathrm{p}<0.0001)$, greater HLA mismatch $(\mathrm{p}=0.006)$, and older age $(\mathrm{p}=0.0009)$. Higher total graft cell dose $(\mathrm{p}=0.001)$, $\mathrm{CD} 34^{+}$cell dose $(\mathrm{p}=0.014)$ and $C D 3^{+}$cell dose $(0.014)$ were associated with lower probability of death due to OI at 6 months.

Since treatment with TBI was closely related to age two multivariable models were fit. Model 1 included; CMV ( $\mathrm{p}=0.0004)$, HLA mismatch $(\mathrm{p}=0.042)$ and Age $(\mathrm{p}=0.03)$. Model 2 included; CMV ( $\mathrm{p}<0.0001)$, HLA mismatch $(\mathrm{p}=0.005)$ and malignancy without TBI $(\mathrm{p}=0.04)$. Since total graft cell dose, $\mathrm{CD} 34^{+}$cell dose and $\mathrm{CD}^{+}$cell dose were also highly correlated, 
each of these variables was introduced into models 1) and 2) separately. Total graft cell dose was the strongest predictor when cell dose variables were added to Models $1(\mathrm{p}=0.0097)$ and 2 ( $\mathrm{p}=0.004)$. CD $34^{+}$cell dose contributed less significantly to both models ( $\mathrm{p}=0.02$ both models). $\mathrm{CD}^{+}$cell dose did not significantly contribute to Model 1 , however was marginally significant in Model $2(\mathrm{p}=0.05)$. In Model 1 total graft cell dose and $\mathrm{CD} 34^{+}$cell dose replaced age because cell dose $/ \mathrm{kg}$ inversely correlates with age. The percent concordance among these models ranged from $71-75 \%$.

Thus, in the pediatric cohort 6-month death due to OI can be predicted by the following risk factors: older age, positive CMV serology, >1 HLA mismatch, malignancy without TBI, and lower graft cell dose (total, CD34+ and CD3+) [52]. In contrast, gender, race and TBI alone do not predict 6-month death due to OI [52].

\section{Dendritic and $T$ cell subsets at Day +50 after UCBT serve as surrogate markers of protection from OI}

To identify patients who were at increased risk for developing OI in the first 100 days a prospective cross-sectional study has been conducted at $\sim$ day +50 post-UCBT [53], with the latest analysis extended to 111 patients. Utilizing Trucount ${ }^{\mathrm{TM}}$ methodology $[20,54,55]$ 4-color surface and intracellular (ic) FACS was employed to accurately enumerate and characterize lymphocyte ad DC subsets.

All patients received myeloablative conditioning regimes, (TBI/CY, Bu/CY, Bu/MEL, TBI/ MEL) and equine ATG at $30 \mathrm{mg} / \mathrm{kg} /$ day between day-3 to day- 1 . All received identical GvHD prophylaxis consisting of Cyclosporine A plus steroids, slowly tapered after day+21 in the absence of $\geq$ grade II aGvHD).

Various degree of cellular reconstitution is noted for most immune cells except for the absence of B lymphocytes. However, immune reconstitution varied widely.

Table I. lists those immune parameters that remain significant predictors for the presence of de novo developed OI. Figure 2. shows that individuals that develop OI by day +100 have a significantly reduced probability of overall survival (Fig 2A) and that death due to OI is related to Grade III/IV GvHD (Fig 2B). Based on these data [53], and also on data not shown, we hypothesize that the increased prevalence of CD8+ T cells expressing/secreting HLA-DR, IFN $\gamma$, Granzymes A, B, Perforin represent an effort by the emerging immune system to control the infectious agent. These changes accompany down regulation of CD28 and CD27 expression along with CD57 upregulation thus represent an evolution towards effector phenotype and function. Along with the skewing of the T cell profile, significantly fewer CD123+ plasmacytoid/lymphoid DC circulate in those with infection $(\mathrm{p}=0.007)$ demonstrating that antigen presenting cell deficiency occurs along with lymphocyte alterations.

\section{Th1 and Tc1 $\mathrm{T}$ cell subsets measured at $\sim$ day+20 after UCBT, can predict those at risk for OI}

With a recent study we aimed to gain insight into the fate and maturational biology of adoptively transferred naive T cells in the lymphopenic hosts even prior to the onset of OI to develop predictive models for OI incidence in the first 100 days. Blood was obtained at a median 18 days post-UCBT if the WBC exceeded $400 / \mathrm{mm}^{3}$. Circulating T-cell subsets and DC counts were monitored. Since our last report [56] we have analyzed seventy six (76) patients at a median age of 62 months with at least 12 months follow-up. Forty four patients (58\%) presented de novo with OI (>90\% viral) at a median of 35 days. Both the OI+ and OI- patient cohorts had low but equivalent absolute $\mathrm{WBC}, \mathrm{CD}^{+}, \mathrm{CD} 4^{+} \mathrm{T}$ cells, and NK lymphocytes. DC subsets 
were largely undetectable. Strikingly, $40 \%$ of circulating T cells were proliferating $\left(\mathrm{Ki}-67^{+}\right)$, regardless of OI status, reflecting vigorous peripheral expansion reducing the CD45RA ${ }^{+} / \mathrm{CD}^{2} 2 \mathrm{~L}^{+} \mathrm{RTE}$ pool to $<20 \%$ from $>90 \%$ infused in the graft only $2-3$ weeks earlier [20]. While most cells $(67 \% \pm 27 \%)$ expressed a 'memory like' CD45RA ${ }^{-} / \mathrm{CD}^{2} 5 \mathrm{RO}^{+}$ phenotype, a significant population (14 $\pm 28 \%$ ) co-expressed CD45RA and RO. The robust $T$ cell expansion was accompanied by upregulation of markers of activation with a median of $66 \%$ of T cells HLA-DR ${ }^{+}$. Interestingly, $\sim 10 \%$ of the circulating T cells were entering apoptosis (ic activated Caspase-3+), regardless of OI status.

In those who developed OI, significantly higher proportion of the circulating $\mathrm{T}$ cells were $\mathrm{CD}^{+}$(40\% vs. $\left.28 \%, \mathrm{p}=0.04\right)$, expressed CCR-5 (82\% vs. 55\%, $\left.\mathrm{p}=0.009\right)$, were secreting IFN $\gamma$ ( $35 \%$ vs. $12 \%, \mathrm{p}=0.01$ ), and acquired a $\mathrm{CD} 57^{+} / \mathrm{CD} 28^{-}$'effector CTL' phenotype. In patients developing OI significantly more Perforin ${ }^{+} / \mathrm{CD} 8^{+} \mathrm{T}$ cells circulated (48\% vs. $26 \%$, $\mathrm{p}=0.02$ ).

In conclusion, in the immediate post-transplant lymphopenic period extensive $\mathrm{T}$ cell proliferation via peripheral expansion leads to major immunophenotypic alterations accompanied by a gradual loss of the original naïve phenotype. In parallel, new T cell subsets emerge displaying a phenotype associated with antigenic stimulation [57]. We hypothesize that in patients who will develop OI, even clinically undetectable levels of virus could induce phenotypic acquisition of Th1/Tc1 cytotoxic effector profile.

\section{Summary}

There is a great need to learn more about the biology of immune recovery after UCBT. Fundamental gaps in knowledge remain regarding the biology and kinetics of developing antigen-specific protective immunity and understanding the impact of recipient age and immunosuppressive agents. However, there is also realistic hope that clinical translation of new immunotherapy strategies could enhance immune competence after UCBT either by impacting on the thymic-independent early period or by fostering thymic recovery.

\section{Acknowledgements}

The authors thank Joanne Kurtzberg and Nelson Chao for their support and guidance in their studies, Melissa Reese, Luciana Marti, and Richard Vinesett for expert technical help. This work was supported in part by The Childrens' Miracle Network, The National Marrow Donor Program-Marrow Transplant Research Grant (P.Sz.), and 1PO1HL-67314-01A1 (P.Sz. and D.N., PI N.Chao)

\section{References}

1. Gluckman E, Broxmeyer HA, Auerbach AD, Friedman HS, Douglas GW, Devergie A, Esperou H, Thierry D, Socie G, Lehn P, et al. Hematopoietic reconstitution in a patient with Fanconi's anemia by means of umbilical-cord blood from an HLA-identical sibling. N Engl J Med 1989;321:1174. [PubMed: 2571931]

2. Kurtzberg J, Graham M, Casey J, Olson J, Stevens CE, Rubinstein P. The use of umbilical cord blood in mismatched related and unrelated hemopoietic stem cell transplantation. Blood Cells 1994;20:275. [PubMed: 7749107]

3. Rocha V, Gluckman E. Clinical use of umbilical cord blood hematopoietic stem cells. Biol Blood Marrow Transplant 2006;12:34. [PubMed: 16399582]

4. Barker JN, Davies SM, DeFor T, Ramsay NK, Weisdorf DJ, Wagner JE. Survival after transplantation of unrelated donor umbilical cord blood is comparable to that of human leukocyte antigen-matched unrelated donor bone marrow: results of a matched-pair analysis. Blood 2001;97:2957. [PubMed: 11342417]

5. Rocha V, Cornish J, Sievers EL, Filipovich A, Locatelli F, Peters C, Remberger M, Michel G, Arcese W, Dallorso S, Tiedemann K, Busca A, Chan KW, Kato S, Ortega J, Vowels M, Zander A, Souillet 
G, Oakill A, Woolfrey A, Pay AL, Green A, Garnier F, Ionescu I, Wernet P, Sirchia G, Rubinstein P, Chevret S, Gluckman E. Comparison of outcomes of unrelated bone marrow and umbilical cord blood transplants in children with acute leukemia. Blood 2001;97:2962. [PubMed: 11342418]

6. Rubinstein P, Carrier C, Scaradavou A, Kurtzberg J, Adamson J, Migliaccio AR, Berkowitz RL, Cabbad M, Dobrila NL, Taylor PE, Rosenfield RE, Stevens CE. Outcomes among 562 recipients of placental-blood transplants from unrelated donors. N Engl J Med 1998;339:1565. [PubMed: 9828244]

7. Rocha V, Labopin M, Sanz G, Arcese W, Schwerdtfeger R, Bosi A, Jacobsen N, Ruutu T, de Lima M, Finke J, Frassoni F, Gluckman E. Transplants of umbilical-cord blood or bone marrow from unrelated donors in adults with acute leukemia. N Engl J Med 2004;351:2276. [PubMed: 15564544]

8. Kurtzberg J, Carter SL, Baxter-Lowe LA, Feig SA, Guinan EC, Kamani NR, Kapoor N, Delaney C, Haut PR, Wall D, Kernan NA. Results of the cord blood transplantation study (COBLT): Clinical outcomes of 193 unrelated donor umbilical cord blood transplantation in pediatric patients with malignant conditions. In: [abstract]. Biol Blood Marrow Transplant 2005;2abst 6

9. Laughlin MJ, Eapen M, Rubinstein P, Wagner JE, Zhang MJ, Champlin RE, Stevens C, Barker JN, Gale RP, Lazarus HM, Marks DI, van Rood JJ, Scaradavou A, Horowitz MM. Outcomes after transplantation of cord blood or bone marrow from unrelated donors in adults with leukemia. N Engl J Med 2004;351:2265. [PubMed: 15564543]

10. Parody R, Martino R, Rovira M, Vazquez L, Vazquez MJ, de la Camara R, Blazquez C, FernandezAviles F, Carreras E, Salavert M, Jarque I, Martin C, Martinez F, Lopez J, Torres A, Sierra J, Sanz GF. Severe infections after unrelated donor allogeneic hematopoietic stem cell transplantation in adults: comparison of cord blood transplantation with peripheral blood and bone marrow transplantation. Biol Blood Marrow Transplant 2006;12:734. [PubMed: 16785063]

11. Barker JN, Hough RE, Van Burik JA, Defor TE, Macmillan ML, O'Brien MR, Wagner JE. Serious infections after unrelated donor transplantation in 136 children: impact of stem cell source. Biol Blood Marrow Transplant 2005;11:362. [PubMed: 15846290]

12. Cohen G, Carter SL, Weinberg KI, Masinsin B, Guinan E, Kurtzberg J, Wagner JE, Kernan NA, Parkman R. Antigen-specific T-lymphocyte function after cord blood transplantation. Biol Blood Marrow Transplant 2006;12:1335. [PubMed: 17162216]

13. Parkman R, Weinberg KI. Immunological reconstitution following bone marrow transplantation. Immunol Rev 1997;157:73. [PubMed: 9255623]

14. Crooks GM, Weinberg K, Mackall C. Immune reconstitution: from stem cells to lymphocytes. Biol Blood Marrow Transplant 2006;12:42. [PubMed: 16399583]

15. Fry TJ, Mackall CL. Immune reconstitution following hematopoietic progenitor cell transplantation: challenges for the future. Bone Marrow Transplant 2005;35(Suppl 1):S53. [PubMed: 15812532]

16. Mackall CL, Bare CV, Granger LA, Sharrow SO, Titus JA, Gress RE. Thymic-independent T cell regeneration occurs via antigen-driven expansion of peripheral $\mathrm{T}$ cells resulting in a repertoire that is limited in diversity and prone to skewing. J Immunol 1996;156:4609. [PubMed: 8648103]

17. Talvensaari K, Clave E, Douay C, Rabian C, Garderet L, Busson M, Garnier F, Douek D, Gluckman E, Charron D, Toubert A. A broad T-cell repertoire diversity and an efficient thymic function indicate a favorable long-term immune reconstitution after cord blood stem cell transplantation. Blood 2002;99:1458. [PubMed: 11830500]

18. Han P, Hodge G, Story C, Xu X. Phenotypic analysis of functional T-lymphocyte subtypes and natural killer cells in human cord blood: relevance to umbilical cord blood transplantation. Br J Haematol 1995;89:733. [PubMed: 7772509]

19. D'Arena G, Musto P, Cascavilla N, Di Giorgio G, Fusilli S, Zendoli F, Carotenuto M. Flow cytometric characterization of human umbilical cord blood lymphocytes: immunophenotypic features. Haematologica 1998;83:197. [PubMed: 9573672]

20. Szabolcs P, Park KD, Reese M, Marti L, Broadwater G, Kurtzberg J. Coexistent naive phenotype and higher cycling rate of cord blood T cells as compared to adult peripheral blood. Exp Hematol 2003;31:708. [PubMed: 12901976]

21. Broxmeyer, HE. Cord blood : biology, immunology, and clinical transplantation. Bethesda, Md.: Bethesda, Md: 2004. American Association of Blood Banks.

22. Chalmers IM, Janossy G, Contreras M, Navarrete C. Intracellular cytokine profile of cord and adult blood lymphocytes. Blood 1998;92:11. [PubMed: 9639493] 
23. Risdon G, Gaddy J, Stehman FB, Broxmeyer HE. Proliferative and cytotoxic responses of human cord blood T lymphocytes following allogeneic stimulation. Cell Immunol 1994;154:14. [PubMed: 8118883]

24. Mommaas B, Stegehuis-Kamp JA, van Halteren AG, Kester M, Enczmann J, Wernet P, Kogler G, Mutis T, Brand A, Goulmy E. Cord blood comprises antigen-experienced T cells specific for maternal minor histocompatibility antigen HA-1. Blood 2005;105:1823. [PubMed: 15498856]

25. Suen Y, Lee SM, Qian J, van de Ven C, Cairo MS. Dysregulation of lymphokine production in the neonate and its impact on neonatal cell mediated immunity. Vaccine 1998;16:1369. [PubMed: 9711774]

26. Bradley MB, Cairo MS. Cord blood immunology and stem cell transplantation. Hum Immunol 2005;66:431. [PubMed: 15935881]

27. Kaminski BA, Kadereit S, Miller RE, Leahy P, Stein KR, Topa DA, Radivoyevitch T, Veigl ML, Laughlin MJ. Reduced expression of NFAT-associated genes in UCB versus adult CD4+ T lymphocytes during primary stimulation. Blood 2003;102:4608. [PubMed: 12946996]

28. Berthou C, Legros-Maida S, Soulie A, Wargnier A, Guillet J, Rabian C, Gluckman E, Sasportes M. Cord blood T lymphocytes lack constitutive perforin expression in contrast to adult peripheral blood T lymphocytes. Blood 1995;85:1540. [PubMed: 7534135]

29. Takahata Y, Nomura A, Takada H, Ohga S, Furuno K, Hikino S, Nakayama H, Sakaguchi S, Hara T. CD25+CD4+ T cells in human cord blood: an immunoregulatory subset with naive phenotype and specific expression of forkhead box p3 (Foxp3) gene. Exp Hematol 2004;32:622. [PubMed: 15246158]

30. Godfrey WR, Spoden DJ, Ge YG, Baker SR, Liu B, Levine BL, June CH, Blazar BR, Porter SB. Cord blood CD4(+)CD25(+)-derived T regulatory cell lines express FoxP3 protein and manifest potent suppressor function. Blood 2005;105:750. [PubMed: 15374887]

31. Schonland SO, Zimmer JK, Lopez-Benitez CM, Widmann T, Ramin KD, Goronzy JJ, Weyand CM. Homeostatic control of T-cell generation in neonates. Blood 2003;102:1428. [PubMed: 12714521]

32. Gardiner CM, Meara AO, Reen DJ. Differential cytotoxicity of cord blood and bone marrow-derived natural killer cells. Blood 1998;91:207. [PubMed: 9414286]

33. Harris DT, Schumacher MJ, Locascio J, Besencon FJ, Olson GB, DeLuca D, Shenker L, Bard J, Boyse EA. Phenotypic and functional immaturity of human umbilical cord blood T lymphocytes. Proc Natl Acad Sci U S A 1992;89:10006. [PubMed: 1438190]

34. Roth I, Corry DB, Locksley RM, Abrams JS, Litton MJ, Fisher SJ. Human placental cytotrophoblasts produce the immunosuppressive cytokine interleukin 10. J Exp Med 1996;184:539. [PubMed: 8760807]

35. Munn DH, Zhou M, Attwood JT, Bondarev I, Conway SJ, Marshall B, Brown C, Mellor AL. Prevention of allogeneic fetal rejection by tryptophan catabolism. Science 1998;281:1191. [PubMed: 9712583]

36. Szekeres-Bartho J, Faust Z, Varga P, Szereday L, Kelemen K. The immunological pregnancy protective effect of progesterone is manifested via controlling cytokine production. Am J Reprod Immunol 1996;35:348. [PubMed: 8739452]

37. Marchant A, Goldman M. T cell-mediated immune responses in human newborns: ready to learn? Clin Exp Immunol 2005;141:10. [PubMed: 15958064]

38. Guller S, LaChapelle L. The role of placental Fas ligand in maintaining immune privilege at maternalfetal interfaces. Semin Reprod Endocrinol 1999;17:39. [PubMed: 10406074]

39. Ribeiro-do-Couto LM, Boeije LC, Kroon JS, Hooibrink B, Breur-Vriesendorp BS, Aarden LA, Boog CJ. High IL-13 production by human neonatal T cells: neonate immune system regulator? Eur J Immunol 2001;31:3394. [PubMed: 11745358]

40. White GP, Watt PM, Holt BJ, Holt PG. Differential patterns of methylation of the IFN-gamma promoter at $\mathrm{CpG}$ and non-CpG sites underlie differences in IFN-gamma gene expression between human neonatal and adult CD45RO- T cells. J Immunol 2002;168:2820. [PubMed: 11884451]

41. Goriely S, Van Lint C, Dadkhah R, Libin M, De Wit D, Demonte D, Willems F, Goldman M. A defect in nucleosome remodeling prevents IL-12(p35) gene transcription in neonatal dendritic cells. J Exp Med 2004;199:1011. [PubMed: 15051764] 
42. Goriely S, Vincart B, Stordeur P, Vekemans J, Willems F, Goldman M, De Wit D. Deficient IL-12 (p35) gene expression by dendritic cells derived from neonatal monocytes. J Immunol 2001;166:2141. [PubMed: 11160266]

43. Langrish CL, Buddle JC, Thrasher AJ, Goldblatt D. Neonatal dendritic cells are intrinsically biased against Th-1 immune responses. Clin Exp Immunol 2002;128:118. [PubMed: 11982599]

44. Tu W, Chen S, Sharp M, Dekker C, Manganello AM, Tongson EC, Maecker HT, Holmes TH, Wang Z, Kemble G, Adler S, Arvin A, Lewis DB. Persistent and selective deficiency of CD4+ T cell immunity to cytomegalovirus in immunocompetent young children. J Immunol 2004;172:3260. [PubMed: 14978134]

45. Klein AK, Patel DD, Gooding ME, Sempowski GD, Chen BJ, Liu C, Kurtzberg J, Haynes BF, Chao NJ. T-Cell recovery in adults and children following umbilical cord blood transplantation. Biol Blood Marrow Transplant 2001;7:454. [PubMed: 11569891]

46. Moretta A, Maccario R, Fagioli F, Giraldi E, Busca A, Montagna D, Miniero R, Comoli P, Giorgiani G, Zecca M, Pagani S, Locatelli F. Analysis of immune reconstitution in children undergoing cord blood transplantation. Exp Hematol 2001;29:371. [PubMed: 11274766]

47. Brahmi Z, Hommel-Berrey G, Smith F, Thomson B. NK cells recover early and mediate cytotoxicity via perforin/granzyme and Fas/FasL pathways in umbilical cord blood recipients. Hum Immunol 2001;62:782. [PubMed: 11476901]

48. Niehues T, Rocha V, Filipovich AH, Chan KW, Porcher R, Michel G, Ortega JJ, Wernet P, Gobel U, Gluckman E, Locatelli F. Factors affecting lymphocyte subset reconstitution after either related or unrelated cord blood transplantation in children -- a Eurocord analysis. Br J Haematol 2001;114:42. [PubMed: 11472343]

49. Thomson BG, Robertson KA, Gowan D, Heilman D, Broxmeyer HE, Emanuel D, Kotylo P, Brahmi $\mathrm{Z}$, Smith FO. Analysis of engraftment, graft-versus-host disease, and immune recovery following unrelated donor cord blood transplantation. Blood 2000;96:2703. [PubMed: 11023501]

50. Koh LP, Chao NJ. Umbilical cord blood transplantation in adults using myeloablative and nonmyeloablative preparative regimens. Biol Blood Marrow Transplant 2004;10:1. [PubMed: 14752775]

51. Parkman R, Cohen G, Carter SL, Weinberg KI, Masinsin B, Guinan E, Kurtzberg J, Wagner JE, Kernan NA. Successful immune reconstitution decreases leukemic relapse and improves survival in recipients of unrelated cord blood transplantation. Biol Blood Marrow Transplant 2006;12:919. [PubMed: 16920557]

52. Szabolcs PP, Niedzwiecki DBL, Chao N, Kurtzberg J. Multivariate Analysis of Patient and Graft Specific Factors among 330 Recipients of Unrelated Cord Blood Transplant (UCBT) To Predict Risk of Death from Opportunistic Infections in the First 6 Months after UCBT. [abstract]. Blood 2006;108 (11):2860a.

53. Szabolcs P, Park KD, Marti L, Reese M, Lee M, DeOliveira Sanders L, Niedzwiecki D, Kurtzberg J. The impact of immune reconstitution in the early post grafting period on the development of opportunistic infections after unrelated cord blood transplantation: a multivariate analysis of host, graft, and day +50 immune profile. . [abstract]. Biology of Blood and Marrow Transplantation 2004;10(2):24, 48a.

54. Szabolcs P, Park KD, Reese M, Marti L, Broadwater G, Kurtzberg J. Absolute values of dendritic cell subsets in bone marrow, cord blood, and peripheral blood enumerated by a novel method. Stem Cells 2003;21:296. [PubMed: 12743324]

55. Szabolcs P, Park KD, Marti L, Deoliveria D, Lee YA, Colvin MO, Kurzberg J. Superior depletion of alloreactive $\mathrm{T}$ cells from peripheral blood stem cell and umbilical cord blood grafts by the combined use of trimetrexate and interleukin-2 immunotoxin. Biol Blood Marrow Transplant 2004;10:772. [PubMed: 15505608]

56. Szabolcs P, Lee YA, Reese M, Chao N, Kurtzberg J. Rapid In Vivo Acquisition of Effector Tc1 Phenotype Prior to Myeloid Engraftment Predicts Opportunistic Infections in Unrelated Cord Blood Transplant Recipients. . [abstract]. Biology of Blood and Marrow Transplantation 2006;12(2):S1.abst 238

57. Hamann D, Baars PA, Rep MH, Hooibrink B, Kerkhof-Garde SR, Klein MR, van Lier RA. Phenotypic and functional separation of memory and effector human CD8+ T cells. J Exp Med 1997;186:1407. [PubMed: 9348298] 


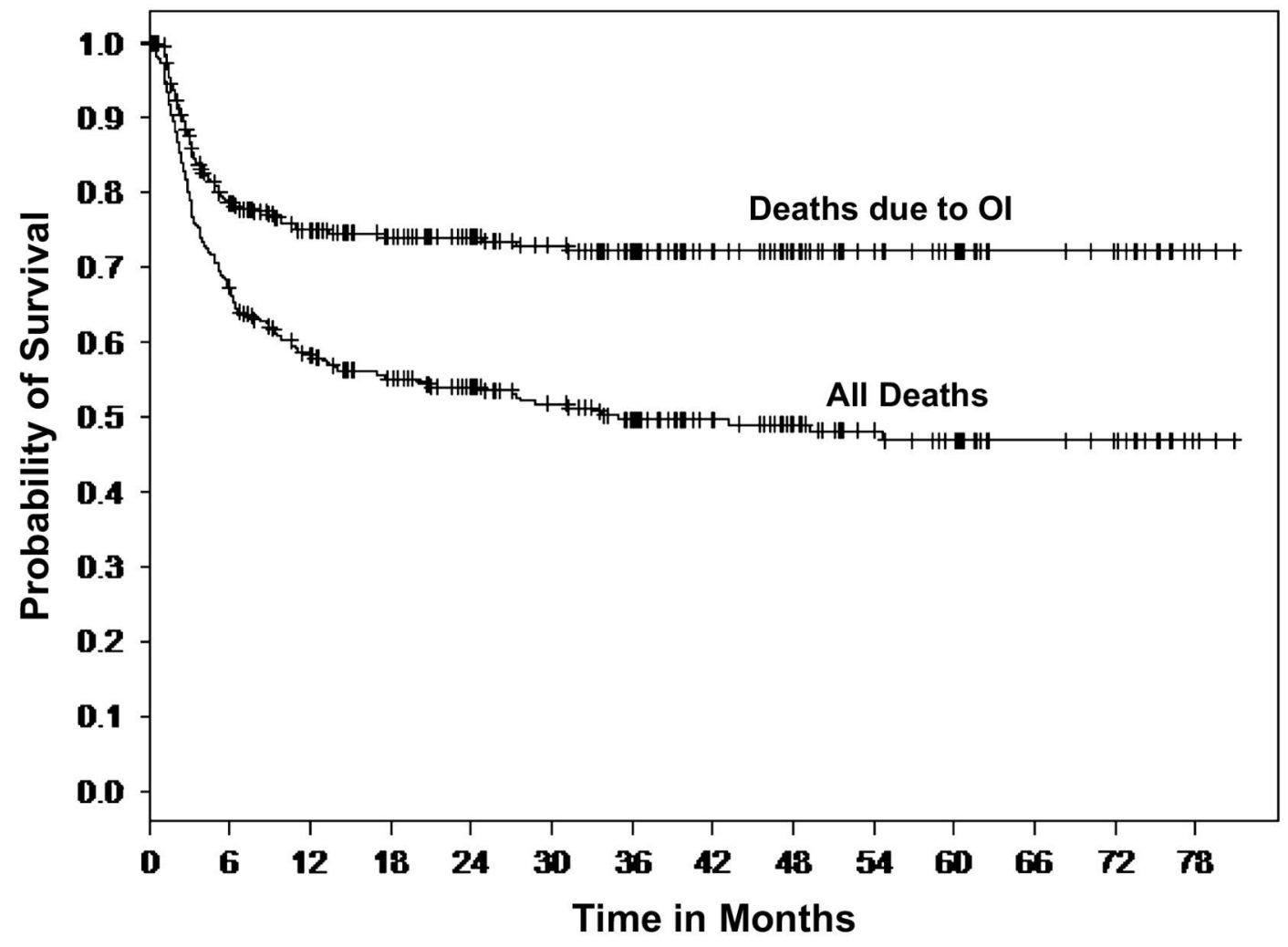

Figure 1. Kaplan-Meier curve of survival (months) after UCBT in 330 consecutive pts Death related to OI is the major cause of failure, most occurring by 6 months. Reproduced with permission from Cytotherapy @2007, Informa Healthcare Journals 
A.
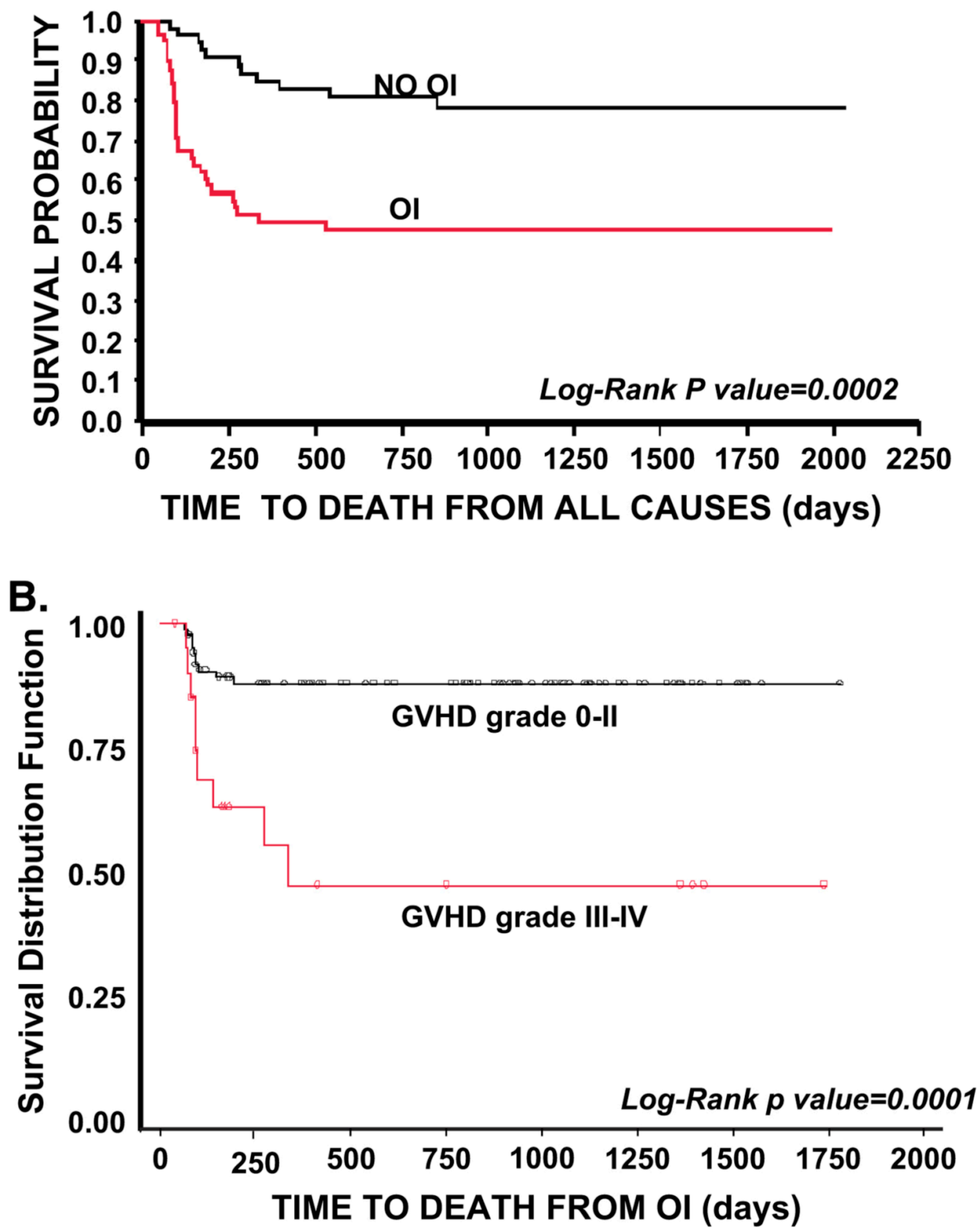

Figure 2.

A) Time to death from all causes in the "Day 50" cohort by Opportunistic Infection status. 2B.) Time to death from OI by presence or absence of severe GvHD. Reproduced with permission from Cytotherapy $\odot 2007$, Informa Healthcare Journals 
Table I

Continuous variables of immunity associated with OI incidence in the first 100 days. Measurements in the "Day +50 study" group

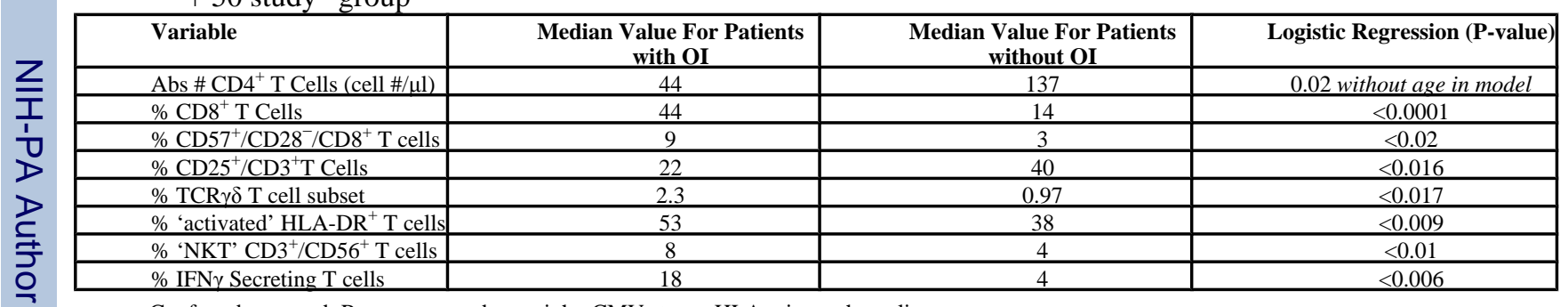

Confounders tested: Race, age, gender, weight, CMV status, HLA mismatch, malignancy,

TBI, GvHD, High Dose steroid pulse (yes, no), Anti-CD25/Daclizumab pulse (yes, no), infused total cell dose/kg, CD34+ cell/kg, CD3+ T cell dose/kg. 